\title{
Climate warming and vegetation response after Heinrich event 1 (16 700-16 000 cal yr BP) in Europe south of the Alps
}

\author{
S. Samartin ${ }^{1}$, O. Heiri ${ }^{1}$, A. F. Lotter ${ }^{2}$, and W. Tinner ${ }^{1}$ \\ ${ }^{1}$ Oeschger Centre for Climate Change Research and Institute of Plant Sciences, University of Bern, Altenbergrain 21, \\ 3013 Bern, Switzerland \\ ${ }^{2}$ Palaeoecology, Department of Physical Geography, Laboratory of Palaeobotany and Palynology, Utrecht University, \\ Budapestlaan 4, CD 3584 Utrecht, The Netherlands
}

Correspondence to: S. Samartin (stephanie.samartin@ips.unibe.ch)

Received: 30 March 2012 - Published in Clim. Past Discuss.: 3 May 2012

Revised: 1 November 2012 - Accepted: 12 November 2012 - Published: 27 November 2012

\begin{abstract}
Chironomids preserved in a sediment core from Lago di Origlio ( $416 \mathrm{~m}$ a.s.l.), a lake in the foreland of the Southern Swiss Alps, allowed quantitative reconstruction of Late Glacial and Early Holocene summer temperatures using a combined Swiss-Norwegian temperature inference model based on chironomid assemblages from 274 lakes. We reconstruct July air temperatures of ca. $10^{\circ} \mathrm{C}$ between 17300 and $16000 \mathrm{cal}$ yr BP, a rather abrupt warming to ca. $12.0^{\circ} \mathrm{C}$ at ca. $16500-16000 \mathrm{cal} \mathrm{yr} \mathrm{BP}$, and a strong temperature increase at the transition to the Bølling/Allerød interstadial with average temperatures of about $14^{\circ} \mathrm{C}$. During the Younger Dryas and earliest Holocene similar temperatures are reconstructed as for the interstadial. The rather abrupt warming at $16500-16000$ cal yr BP is consistent with sea-surface temperature as well as speleothem records, which indicate a warming after the end of Heinrich event 1 (sensu stricto) and before the Bølling/Allerød interstadial in southern Europe and the Mediterranean Sea. Pollen records from Origlio and other sites in southern Switzerland and northern Italy indicate an early reforestation of the lowlands 2000-1500 yr prior to the large-scale afforestation of Central Europe at the onset of the Bølling/Allerød period at ca. $14700-14600 \mathrm{cal}$ yr BP. Our results suggest that these early afforestation processes in the formerly glaciated areas of northern Italy and southern Switzerland have been promoted by increasing temperatures.
\end{abstract}

\section{Introduction}

Synchronous early afforestation processes occurred over wide areas in the lowlands of southern Switzerland and northern Italy at $\sim 16000$ cal yr BP (Vescovi et al., 2007), about 1.5 millennia prior to the onset of the Bølling/Allerød warming recorded in continental Europe (e.g. Lang, 1994; Lotter et al., 2012) and in the Greenland ice cores (GI-1, at ca. 14650 cal yr BP before 1950, Svensson et al., 2008). Climatic warming was suggested as an explanation of the early forest expansion south of the Alps (Vescovi et al., 2007), but local non-pollen evidence for a climatic warming prior to the Bølling/Allerød, necessary to confirm this hypothesis, is presently still lacking. In contrast, afforestation north of the Alps only began at the onset of the Bølling/Allerød warming at 14700-14500 cal yr BP (e.g. Lotter, 1999; Litt et al., 2001, 2003), which is well documented in many terrestrial multiproxy records in the region (e.g. Lotter et al., 2012).

Carbon-isotope measurements in stalagmites from Southern France and northern Turkey suggest an early warming between $\sim 16000$ and $\sim 15900$ cal yr BP (Genty et al., 2006; Fleitmann et al., 2009). This early age seems in disagreement with the later and abrupt climatic warming observed during the transition from a glacial to an interglacial climate in ice core records from Greenland (Svensson et al., 2008). However, several late Quaternary sea surface temperature reconstructions from the Mediterranean, the North Atlantic, and the North Pacific indicate an early warming event starting between $\sim 18000$ and $\sim 16750$ cal yr BP (Chapman et al., 1996; Cacho et al., 1999, 2001; Hill et al., 2006). 

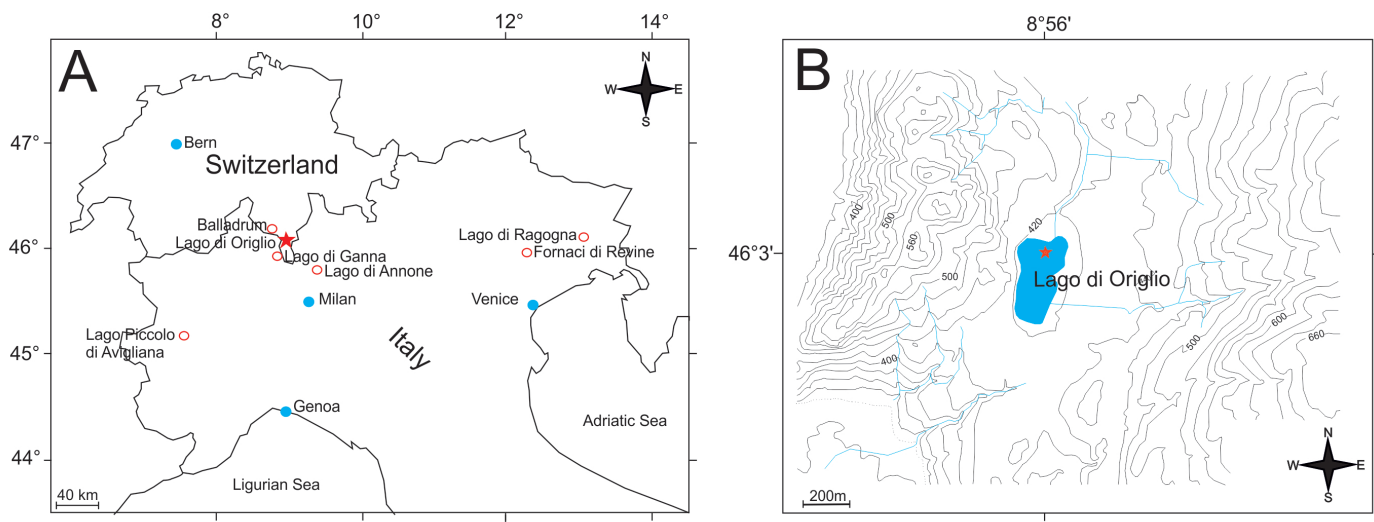

Fig. 1. Map showing the location of the study site. (A) Location of Lago di Origlio within Switzerland (star) and other lowland sites with early afforestation in southern Switzerland and northern Italy (red circles): Lago di Annone (Wick, 1996), Balladrum (Hofstetter et al., 2006), Fornaci di Revine (Friedrich et al., 1999), Lago di Ganna (Schneider and Tobolski, 1985), Lago Piccolo di Avigliana (Finsinger et al., 2006), and Lago di Ragogna (Wick, 2004); (B) Detailed map of the lake, the star indicates the exact location of the core.

Considering the chronological uncertainties, climatic warming may have coincided with the end of Heinrich event 1 at ca. $16700 \mathrm{cal}$ yr BP and thus be related to an intensification of the meridional overturning circulation in the Atlantic Ocean (McManus et al., 2004). In this paper we use Heinrich event 1 (HE-1) following the definition of Stanford et al. (2011) for the Heinrich event 1 sensu stricto (1750016700 cal yr BP).

The analysis of chironomid remains in lake sediments has the potential to detect summer temperature change at different temporal scales during the Late Glacial and the Holocene. The strong relationship between the distribution of chironomids and summer air temperature (Lotter et al., 1997; Brooks and Birks, 2001; Heiri and Lotter, 2005) has led to the development of chironomid-based inference models for reconstructing past summer temperatures (so-called transfer functions) and allowed chironomid-based palaeotemperature records to be produced (Brooks, 2006). Many chironomidbased palaeoclimate reconstructions from the alpine region (e.g. Heiri et al., 2003; Heiri and Lotter, 2005; Ilyashuk et al., 2009) and elsewhere in the North Atlantic realm (e.g. Brooks, 1997; Brooks and Birks, 2000; Heiri et al., 2007a) have documented marked climatic shifts during the Late Glacial and Early Holocene period.

Here we present a new chironomid record and quantitative chironomid-based July air temperature reconstruction covering the latest Pleistocene and earliest Holocene ca. 1800011000 cal yr BP from Lago di Origlio (416 m a.s.l.), a lake in the foreland of the Southern Alps of Switzerland. We address the question whether early afforestation south of the Alps coincided with local climate warming prior to the onset of the late-glacial Bølling/Allerød interstadial. Furthermore, we explore patterns of Late Glacial climatic change in Europe and the Mediterranean realm and discuss potential links between climate change and vegetation response after the end of HE-1.

\section{Material and methods}

\subsection{Site description}

Lago di Origlio is a small eutrophic lake (Müller et al., $1998)$ located at an elevation of $416 \mathrm{~m}$ a.s.l. $\left(46^{\circ} 3^{\prime} 3.95^{\prime \prime} \mathrm{N}\right.$, $8^{\circ} 56^{\prime} 32.8^{\prime \prime} \mathrm{E}$ ) in southern Switzerland (canton Ticino), in the foreland of the Southern Alps, approximately $5 \mathrm{~km}$ north of Lugano (Fig. 1). It has a slightly elongated shape and a surface area of about $8 \mathrm{ha}$, with a minor inlet on the east and an outlet in the north. The climate at present is warm temperate with considerable precipitation during the summer months. The so-called "Insubrian" climate is thus in contrast to the "Mediterranean" climate, which is characterized by more or less pronounced summer drought (Veit, 2002). Monthly mean air temperature and precipitation for the period 1961-1990, interpolated to a 1 ha grid (Thornton et al., 1997), suggest mean January and July air temperature at Origlio of $2.1^{\circ} \mathrm{C}$ and $20.7^{\circ} \mathrm{C}$, respectively. Mean annual precipitation is estimated to $1743 \mathrm{~mm}$. The local bedrock is composed of Late Pleistocene siliceous deposits and metamorphic crystalline rock (gneiss). The vegetation in the surroundings of the lake is dominated by Castanea sativa, Quercus petraea, Quercus pubescens, Alnus glutinosa, Fraxinus excelsior, Betula pendula, Fagus sylvatica, and Tilia cordata (Tinner et al., 1999) and thus typical for warm temperate submediterranean southern Europe.

\subsection{Coring and sediments}

Two field campaigns were carried out in 1993 and 1994 at Origlio. Parallel cores $1 \mathrm{~m}$ apart from each other were taken with a Streif-Livingstone piston corer (tube diameter $4.8 \mathrm{~cm}$; Merk and Streif, 1970) from the deepest point of the lake $(5.35 \mathrm{~m}) .19 .55 \mathrm{~m}$ of lake sediment were retrieved and the cores were correlated using lithostratigraphic markers. 
Table 1. ${ }^{14} \mathrm{C}$ dates of Origlio (ORE).

\begin{tabular}{|c|c|c|c|c|c|c|}
\hline Lab. No. & Depth $(\mathrm{cm})$ & Core & Material & $\begin{array}{r}{ }^{14} \mathrm{C} \text { dates, } \\
\text { conv. } \\
\text { uncal BP }\end{array}$ & $\begin{array}{r}\text { Calibrated } \\
\text { age } \\
(\text { cal yr BP)* }\end{array}$ & $\begin{array}{r}\text { Cal. } 95 \% \\
\text { confidence } \\
\text { limits* }\end{array}$ \\
\hline UtC-4995 & $1059-1058$ & ORB & $\begin{array}{l}\text { Terr. plant remains, } \\
\text { indet. arboreal bark }\end{array}$ & $7540 \pm 50$ & 8360 & $8288-8421$ \\
\hline UtC-4996 & $1102-1103$ & ORB & Leaf indet. & $8080 \pm 60$ & 9006 & $8760-9141$ \\
\hline UtC-4997 & 1148 & ORB & Twig indet. & $8220 \pm 50$ & 9187 & 9025-9310 \\
\hline UtC-4998 & $1267-1264$ & ORB & Indet. arboreal bark & $9350 \pm 60$ & 10567 & $10392-10731$ \\
\hline UtC-5000 & $1289-1286$ & ORE & Indet. arboreal bark & $10090 \pm 80$ & 11667 & $11321-11989$ \\
\hline UtC-5001 & $1308-1307$ & ORE & Indet. arboreal bark & $10980 \pm 60$ & 12847 & $12675-13071$ \\
\hline UtC-5002 & $1314-1311$ & ORE & Terr. indet. epidermis & $11160 \pm 60$ & 13042 & $12823-13237$ \\
\hline UtC-5003 & 1325 & ORE & Terr. indet. epidermis & $12330 \pm 70$ & 14353 & $14005-14904$ \\
\hline UtC-5004 & 1398 & ORE & Wood & $14520 \pm 80$ & 17498 & $17246-17949$ \\
\hline
\end{tabular}

Plant macrofossils were AMS dated at the Utrecht (UtC-, Holland) Radiocarbon Laboratory. * Calibration of radiocarbon dates: Calib 6.0 (Reimer et al., 2004).

The core section analysed consists of silty gyttja (13.94$13.38 \mathrm{~m})$, slightly silty gyttja $(13.38-13.18 \mathrm{~m})$ and gyttja $(13.18-12.75 \mathrm{~m})$, a detailed description of the sediment is provided in Tinner (1998).

\subsection{Radiocarbon dating and vegetation history}

Radiocarbon ages for Origlio were obtained by Accelerator Mass Spectrometry (AMS) at the Utrecht Radiocarbon Laboratory (the Netherlands) on selected terrestrial plant macrofossils (Table 1). Nine samples of terrestrial plant remains (UtC-4995-4998, UtC-5000-5004) were dated in 1995-1997. Radiocarbon ages were converted to calendar years Before Present (cal yr BP) with the program Calib version 6.0 (Reimer et al., 2004) using the INTCAL09 dataset (Heaton et al., 2009).

The main traits of vegetation history at Origlio during the past $20000 \mathrm{yr}$ were presented in Tinner et al. $(1999,2005)$ and Vescovi et al. (2007). Pollen data suggest that steppic tundra prevailed before ca. $18000 \mathrm{cal} \mathrm{yr} \mathrm{BP.} \mathrm{At} \mathrm{around}$ 18000 cal yr BP Juniperus shrubs expanded into the steppic tundra as evidenced by stomata and pollen. This vegetational change stabilized the soils, while the shift from sandy silt to silty gyttja shows that the erosional input into the lake was significantly reduced. Subsequently, Juniperus stands were replaced by an open Pinus cembra, P. sylvestris, and Betula woodland (stomata and pollen evidence) at ca. $16000 \mathrm{cal} \mathrm{yr} \mathrm{BP}$. This woodland persisted until ca. $14500 \mathrm{cal}$ yr BP, when Pinus sylvestris and tree birch outcompeted Pinus cembra, forming rather closed boreal forests at the onset of the Bølling/Allerød interstadial. After ca. 13200 cal yr BP thermophilous trees such as e.g. Quercus, Ulmus and Tilia expanded in the Origlio area. Steppic plants (e.g. Artemisia) re-expanded at ca. $12800 \mathrm{cal} \mathrm{yr} \mathrm{BP}$ at the onset of the Younger Dryas cooling, but were strongly reduced at the onset of the Holocene at ca. $11600 \mathrm{cal} \mathrm{BP}$, when Pinus, Betula, and the thermophilous trees recovered.

\subsection{Sampling and analysis of fossil chironomids}

The core was sampled for chironomid analysis at regular $4-5 \mathrm{~cm}$ intervals between 12.76 and $13.94 \mathrm{~m}$ depth, using about $10-20 \mathrm{~cm}^{3}$ of wet sediment ( $1 \mathrm{~cm}$ thick slices). In total 28 samples were taken from the sediment cores of Origlio. The sediment samples were sieved through a $100 \mu \mathrm{m}$ sieve without any chemical pretreatment. Chironomid head capsules were sorted in a Bogorov tray under a stereomicroscope (30-50 × magnification), dried, and mounted in $\mathrm{Eu}-$ paral for taxonomic identification. The taxa were identified at $100-400 \times$ magnification under a compound microscope. A minimum count sum of 50 head capsules per sample was aimed for (Heiri and Lotter, 2001). However, 12 samples yielded count sums below this threshold (10-43 headcapsules). Head capsules containing a complete mentum were counted as one, head capsules containing half a mentum were counted as half, while head capsules with less than half a mentum were disregarded. Taxonomic identification followed Wiederholm (1983), Schmid (1993), Rieradevall and Brooks (2001), and Brooks et al. (2007).

\subsection{Numerical analysis}

To summarize major compositional changes of chironomid assemblages through time, a detrended correspondence analysis (DCA) was conducted using the program CANOCO 4.5 (ter Braak and Šmilauer, 2002). The DCA was performed on square-root transformed percentage data and with downweighting of rare taxa. The gradient length of the first DCA axis was 2.7 standard deviation units, justifying unimodal response models (Birks, 1995). The chironomid record was partitioned into zones with the optimal sum of squares partitioning method (Birks and Gordon, 1985) as implemented 
in ZONE, version 1.2, written by Steve Juggins (University of Newcastle). The number of statistically significant assemblage zones was determined using the broken-stick approach (Bennett, 1996) using BSTICK, version 1.0 (J. M. Line and H. J. B. Birks, unpublished software).

\subsection{Temperature reconstruction}

Quantitative temperature estimates were produced based on the fossil chironomid assemblages using a combined SwissNorwegian temperature inference model (Heiri et al., 2011) consisting of 274 lakes covering a July air temperature range of 3.5 to $18.4^{\circ} \mathrm{C}$ and including information on the distribution of 154 chironomid taxa. This combined dataset has the advantage that it contains distributional data on most chironomid taxa expected to occur during the late Quaternary in European lake sediments and it covers a larger temperature range than most other existing regional calibration datasets.

A weighted averaging partial least squares model (WAPLS; ter Braak and Juggins, 1993; ter Braak et al., 1993) with two components was used for reconstruction. The model features a cross-validated root mean square error of prediction (RMSEP) of $1.55^{\circ} \mathrm{C}$, a mean bias of $1.35^{\circ} \mathrm{C}$, a maximum bias of $-0.008^{\circ} \mathrm{C}$, and a cross-validated coefficient of determination $\left(\mathrm{r}^{2}\right)$ of 0.84 between observed and inferred July air temperatures. Cross validation was based on bootstrapping (9999 cycles) and calculations were based on square root transformed percentage data.

\subsection{Reconstruction diagnostics}

Five numerical criteria were calculated to evaluate the reliability of the chironomid-inferred temperature reconstruction (Birks et al., 2010): the sample specific standard error of prediction (SSPE); the chi-square distance (dissimilarity coefficient) to the closest modern analogue to identify if any fossil assemblages lack "good" modern analogues within the modern calibration dataset; the goodness-of-fit measures derived from canonical correspondence analysis (CCA) of the modern and fossil data with July air temperature as the sole constraining variable to evaluate the fit of fossil assemblages to this variable; the percentage of rare taxa (Hill, 1973; N2 <5); and the percentage of taxa not occurring in the training set.

Chi-square distance and Hill's N2 values were calculated using C2 (Juggins, 2007), and CCA was carried out with the program CANOCO 4.5 (ter Braak and Šmilauer, 2002). Fossil assemblages with a squared chi-square distance to the most similar sample in the modern calibration dataset larger than the 2nd and 5th percentile of all squared chi-square distances in the modern assemblage data were identified as samples with "no close" and "no good" analogue, respectively (Birks et al., 1990). Samples with a residual distance to axis one higher than the extreme 10 and $5 \%$ of all residual distances in the modern calibration dataset when calculating a CCA with July air temperature as sole explanatory variable

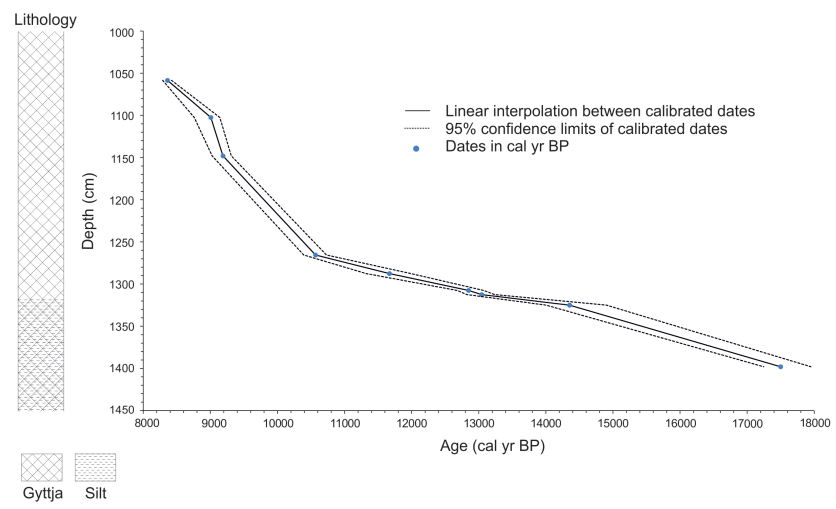

Fig. 2. Age-depth model of the Origlio record including lithological description of the sediments. AMS ${ }^{14} \mathrm{C}$ ages were obtained from 9 plant macrofossils (see Table 1). The ${ }^{14} \mathrm{C}$ dates were calibrated (cal yr BP) with the program Calib version 6.0 (Reimer et al., 2004) using the IntCal09 dataset (Heaton et al., 2009). The agedepth model is based on linear interpolation.

were considered to have a "poor" and "very poor" fit with temperature, respectively (Birks et al., 1990).

\section{Results}

\subsection{Chronology}

The Origlio age-depth model is constrained by calibrated radiocarbon ages from nine terrestrial plant macrofossils (Table 1). Linear interpolation between the calibrated radiocarbon ages was used to assign individual ages to the samples (Fig. 2). The average $95 \%$ confidence interval of the calibrated ages encompasses $\sim 470 \mathrm{yr}$, suggesting chronological uncertainties of ca. $\pm 235 \mathrm{yr}$ for the record.

\subsection{The Origlio chironomid record}

In total, 64 different chironomid taxa were identified in 28 samples. Twenty-nine taxa had relative abundances lower than $5 \%$. Downcore changes in the chironomid record of Origlio are very pronounced and a selection of taxa is shown in Fig. 3. Five statistically significant assemblage zones were distinguished.

Zone ORE-1 (1394-1363 cm; 17 350-16000 cal yr BP) is dominated by Paracladius, Stictochironomus rosenschoeldi-type, Tanytarsus lugens-type, Heterotrissocladius grimshawi-type, and Paracladopelma, which reach maximum abundances in this zone. Microspectra insignilobustype and Chironomus anthracinus-type show high abundances at the onset and lower abundances towards the end of the zone. The following taxa occur at the transition to zone ORE-2: Dicrotendipes nervosus-type, Pseudochironomus and Tanytarsus pallidicornis-type 2. Chironomid 


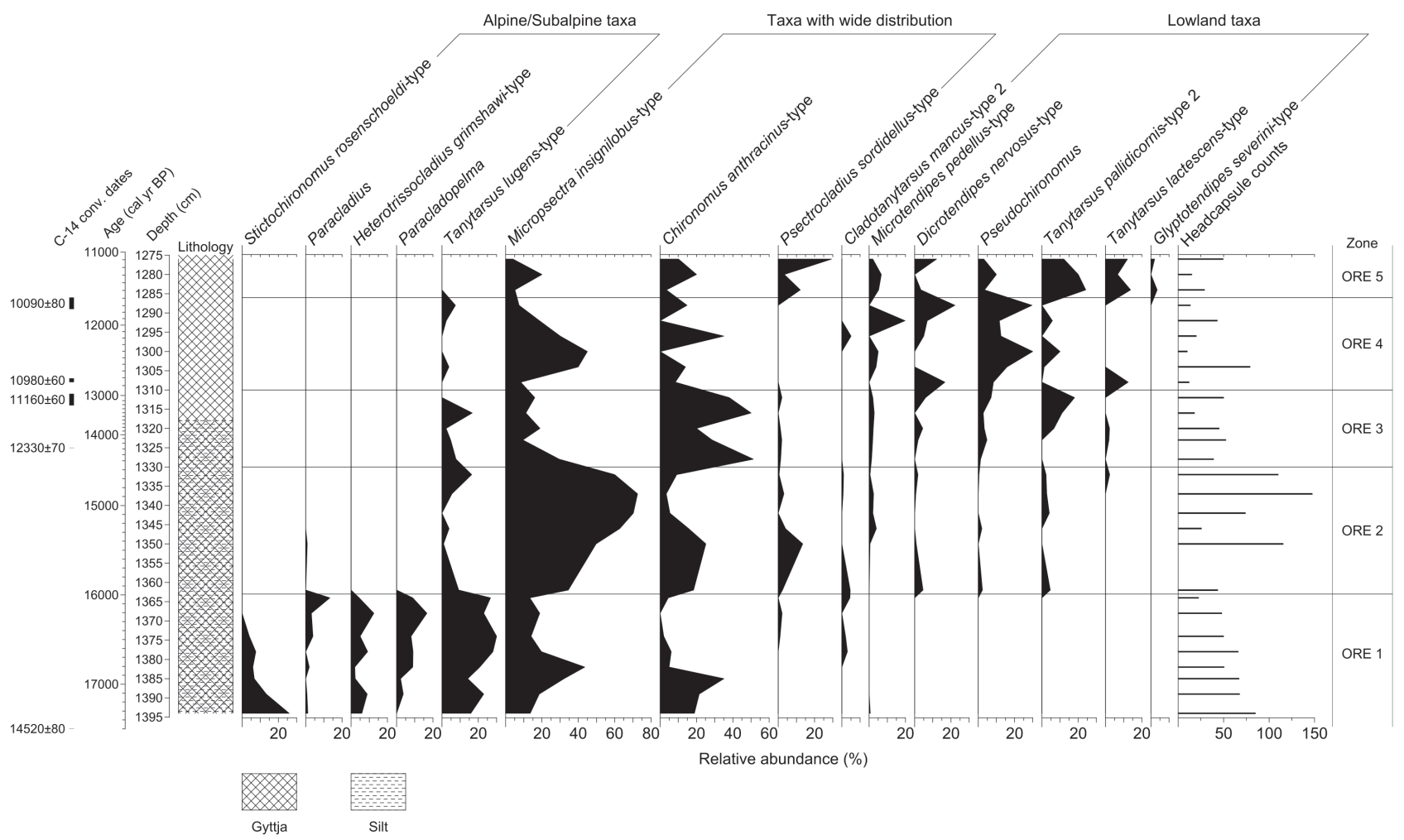

Fig. 3. The Origlio chironomid record. Relative abundances (\%) of selected chironomid taxa and significant chironomid assemblage zones are shown. The chironomids are grouped according to their altitudinal preference in the Swiss Alps (Heiri et al., 2003; Heiri and Lotter, 2010) to support interpretation and highlight trends.

concentrations are on average 2.7 head capsules per $\mathrm{cm}^{3}$ and lowest within the whole record.

Zone ORE-2 (1363-1330 cm; 16000-14 550 cal yr BP) is characterized by the absence of taxa such as Stictochironomus rosenschoeldi-type, Heterotrissocladius grimshawitype, and Paracladopelma. In the middle of the zone Paracladius vanishes entirely from the record, while Tanytarsus lugens-type decreases at the onset and increases again towards the end of the zone. The most dominant taxon is $M i$ crospectra insignilobus-type, which reaches maximum abundances of about $70 \%$. Chironomus anthracinus-type displays high abundances at the onset and lower abundances towards the end of the zone. Dicrotendipes nervosus-type, Pseudochironomus, and Tanytarsus pallidicornis-type 2 persist in low abundances. Microtendipes pedellus-type and Tanytarsus lactescens-type appear for the first time in the record. Chironomid concentrations are on average 8.5 head capsules per $\mathrm{cm}^{3}$ and highest within the whole record.

Zone ORE-3 (1330-1310 cm; 14 550-13 000 cal yr BP) displays a pronounced decrease in Microspectra insignilobus-type and a strong increase in Chironomus anthracinus-type, which reaches maximum abundances in this zone (50\%). Tanytarsus lugens-type is still present. Dicrotendipes nervosus-type, Pseudochironomus, and Tanytarsus pallidicornis-type 2 display higher abundances than in the previous zone and increase towards the end of the zone. $M i$ crotendipes pedellus-type and Tanytarsus lactescens-type are present in almost the same abundances as in zone ORE-2, while the latter taxon increases in this zone. Chironomid concentrations are on average 4 head capsules per $\mathrm{cm}^{3}$.

Zone ORE-4 (1310-1286 cm; 13 000-11 $600 \mathrm{cal} \mathrm{yr} \mathrm{BP)}$ displays a pronounced decrease in Chironomus anthracinustype and a strong increase in Micropsectra insignilobus-type. Tanytarsus lugens-type is present in single samples and low abundances. Microtendipes pedellus-type and Dicrotendipes nervosus-type reach maximum abundances towards the end of the zone. Pseudochironomus displays maximum abundances at the onset and towards the end of the zone. Tanytarsus pallidicornis-type 2 is present in lower abundances than in the previous zone but increases towards the end of the zone. Tanytarsus lactescens-type only occurs in single samples at the onset and the end of the zone, while it is absent in between. Chironomid concentrations are on average 3 head capsules per $\mathrm{cm}^{3}$.

In zone ORE-5 $(1286-1276 \mathrm{~cm} ; \sim 11600-11100 \mathrm{cal}$ yr BP) Micropsectra insignilobus-type and Chironomus anthracinus-type are present in lower abundances than in the previous one. Tanytarsus lugens-type completely disappears from the record. Microtendipes pedellus-type, Dicrotendipes nervosus-type and Pseudochironomus decrease in 
abundance, whereas Tanytarsus pallidicornis-type 2, Tanytarsus lactescens-type, and Glyptotendipes severini increase in abundance at the beginning of the zone. Chironomid concentrations are on average 3 head capsules per $\mathrm{cm}^{3}$.

\subsection{Ordination of the Origlio chironomid record}

Changes in DCA axis 1 sample scores largely coincide with the five statistically significant assemblage zones (ORE-1 to ORE-5) (Fig. 4a). The first two DCA axes explain 48.6 and $12.9 \%$ of the total variance in the chironomid data. The chironomids display a major change in assemblage composition equivalent to $1.5 \mathrm{SD}$ units at the transition from zone ORE-1 to ORE-2 ( 16000 cal yr BP), the changes observed at the transitions between the subsequent zones (ORE-2/3, ORE$3 / 4$ and ORE-4/5) are of far smaller amplitude and range from 0.2 to $0.35 \mathrm{SD}$.

\subsection{Chironomid-inferred temperatures}

Taxa with low taxonomic resolution as for instance unidentified Chironomini, Tanytarsini, Orthocladiinae, Paratanytarsus, Psectrocladius, and Tanytarsus were excluded when inferring temperature. Of the remaining 58 fossil taxa, 53 occur in the transfer function.

When applied to the Origlio chironomid record, the transfer function reconstructed average July air temperatures of $\sim 10^{\circ} \mathrm{C}$ for zone ORE- $1(\sim 17350-16000$ cal yr BP, Fig. 4b). Inferred temperatures abruptly increase by about $2.5^{\circ} \mathrm{C}$ at the onset of zone ORE-2 $(\sim 16000$ cal yr BP $)$ and stay relatively stable around $\sim 11.6^{\circ} \mathrm{C}$ until the end of the zone. Zone ORE-3 $(\sim 14550-13000 \mathrm{cal} \mathrm{yr} \mathrm{BP})$ is characterized by a temperature increase of about $2.5-3.2^{\circ} \mathrm{C}$ at $\sim 14500$ cal yr BP. July air temperatures of zone ORE3 are higher than in the previous zone and on average $13.5^{\circ} \mathrm{C}$. A distinct centennial-scale cooling of $\sim 2.4^{\circ} \mathrm{C}$ seems to occur at $1316 \mathrm{~cm}(\sim 13400 \mathrm{cal} \mathrm{yr} \mathrm{BP})$. However, this change in temperature is based on a single sample. Average July air temperatures of zone ORE-4 are $\sim 15.3^{\circ} \mathrm{C}$, with the first part $(\sim 13000-12300$ cal yr BP $)$, being slightly warmer $\left(\sim 15.8^{\circ} \mathrm{C}\right)$ than the second part $\left(\sim 12300-11600\right.$ cal yr BP, $\left.\sim 14.7^{\circ} \mathrm{C}\right)$. Reconstructed temperatures decrease by about $1.9^{\circ} \mathrm{C}$ between 1304 and $1296 \mathrm{~cm}(\sim 12650-12150 \mathrm{cal}$ yr BP$)$, although the decrease is not very clear in the reconstruction and seems to occur in two steps. In the uppermost part of the record (ORE5; 11 600-11 100 cal yr BP), chironomid-inferred July air temperatures slightly increase by about $0.8^{\circ} \mathrm{C}$. They are on average $\sim 15.1^{\circ} \mathrm{C}$, and, therefore slightly lower than during the previous zone.

\subsection{Evaluation of the inferred temperatures}

The temperature reconstruction for Origlio was characterized by sample specific errors of prediction (SSPE) between 1.5$1.75^{\circ} \mathrm{C}$ (Fig. 4b). An evaluation of the modern analogues for

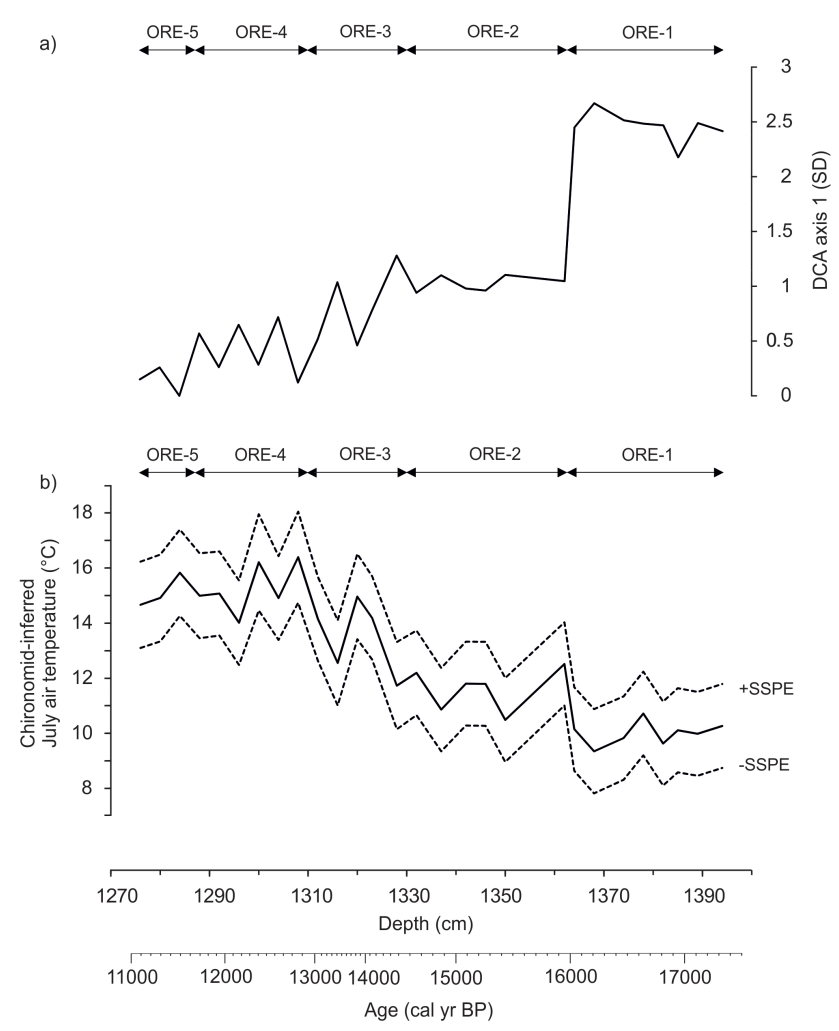

Fig. 4. (a) Sample scores of the first DCA (detrended correspondence analysis) axis of the chironomid assemblages plotted versus sediment depth and age, and (b) chironomid-inferred July air temperatures estimated based on a weighted averaging partial least squares model using the Swiss-Norwegian modern training set (Heiri et al., 2011) (including sample specific error of prediction: SSPE).

fossil assemblages in the modern training set disclosed that ca. $14.3 \%$ of the samples have "no good" and "no close" analogue (two samples from the Younger Dryas and two from the earliest Holocene) and additional $17.9 \%$ have "no close" analogue (one from the Oldest Dryas, two from the Bølling/Allerød, one from the Younger Dryas and one from the earliest Holocene) (Fig. 5a). Goodness-of-fit statistics revealed that $10.7 \%$ of the samples have a "very poor fit" and a "poor fit" to temperature (two from the Bølling/Allerød and one from the Younger Dryas), while $10.7 \%$ of the samples have a "poor fit" with temperature (one from the Oldest Dryas, one from the Younger Dryas and one from the earliest Holocene) (Fig. 5b). In many of the Younger Dryas (ORE-4) and Early Holocene (ORE-5) samples we did not reach a minimum count of 50 head capsules recommended for subfossil chironomid analysis (Heiri and Lotter, 2001). Many of these assemblages are also characterized by a "no good" analogue situation and a 'very poor' fit with temperature. Assemblages with high abundances of Stictochironomus rosenschoeldi-type are unusual in the modern training set and this taxon only occurs in Swiss alpine lakes, whereas 


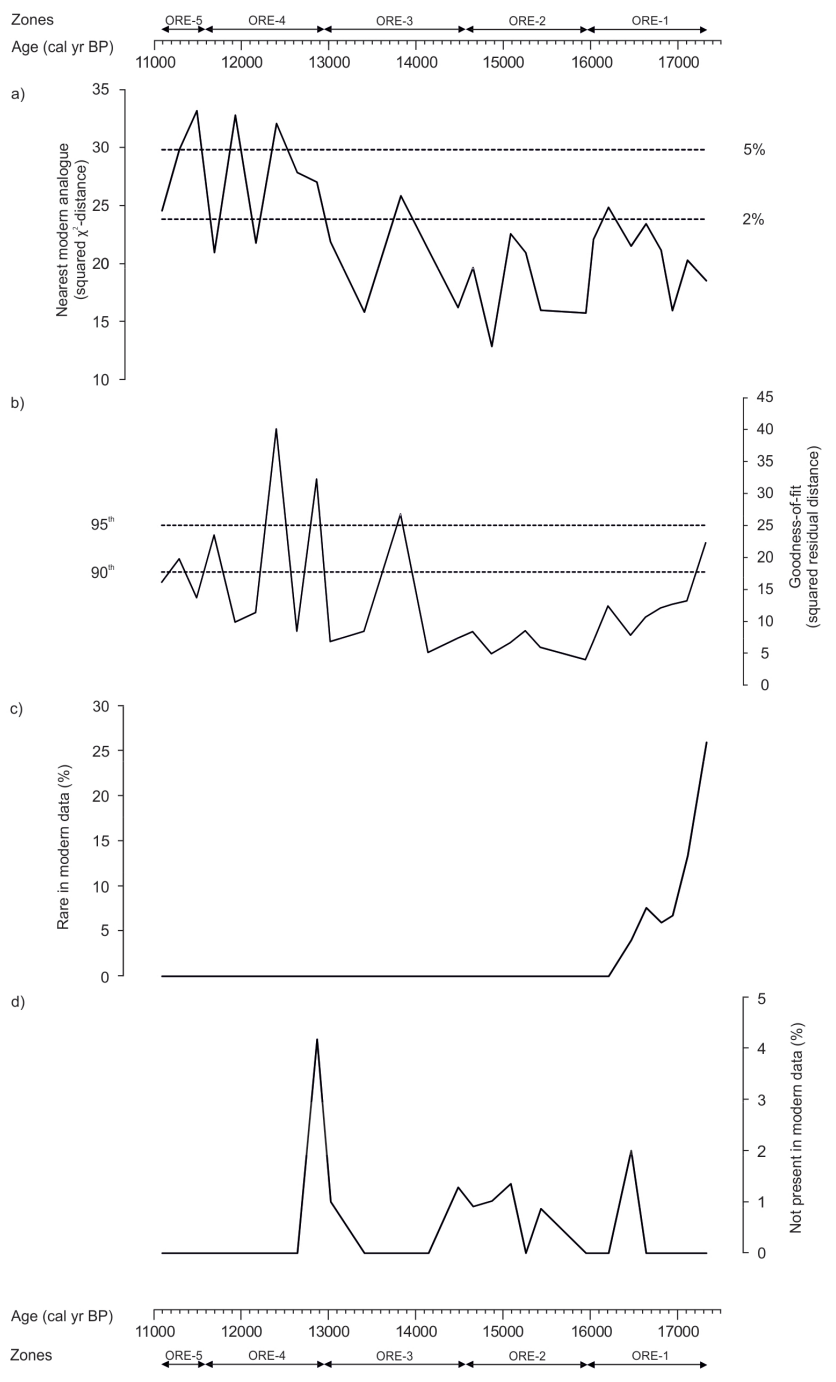

Fig. 5. Diagnostic statistics of the chironomid-inferred July temperature reconstruction for the Origlio record (a-d). (a) Modern analogues for the fossil samples in the calibration data set; (b) goodness-of-fit statistics of the fossil samples with temperatures; (c) percentage of rare chironomid head capsules $(\mathrm{N} 2<5)$; (d) chironomid taxa not represented in the calibration set. Horizontal dashed lines are used to identify samples with "no close" (2\%) and "no good" (5\%) modern analogues, and samples with "poor" (90th percentile) and "very poor fit" (95th percentile) with temperature.

it is absent from Norwegian lakes. This taxon is also identified as "rare" in the modern calibration dataset and solely responsible for the high proportion of rare taxa found during the Oldest Dryas (6-26\%, Fig. 5c). The maximum abundance of taxa not occurring in the modern training set was $\leq 4 \%$ in any given sample (Fig. $5 \mathrm{~d}$ ).

\section{Discussion}

\subsection{Interpretation of faunal trends}

The dominance of taxa typical of cold environments (e.g. Paracladius, Stictochironomus rosenschoeldi-type, Tanytarsus lugens-type, see Heiri and Lotter, 2010) suggests low July air temperatures before $\sim 16000$ cal yr BP (ORE1). For the same section the presence of taxa usually found in the profundal of oligotrophic lakes, such as Stictochironomus rosenschoeldi-type, Tanytarsus lugens-type, Paracladopelma, Heterotrissocladius grimshawi-type, and $\mathrm{Mi}$ cropsectra insignilobus-type (Saether, 1979; Brooks et al., 2007) probably indicates that the lake was deep and relatively nutrient-poor. Towards the end of this zone, warmadapted littoral lowland taxa such as Dicrotendipes nervosus-type, Pseudochironomus, and Tanytarsus pallidicornistype 2 (Heiri et al., 2011) start to increase in abundance, likely as a consequence of warmer climatic conditions.

The disappearance of cold-adapted taxa such as Stictochironomus rosenschoeldi-type, Paracladius, Heterotrissocladius grimshawi-type, and Paracladopelma as well as low abundances of Tanytarsus lugens-type, also a taxon common in cold-water environments (Brooks et al., 2007; Heiri et al., 2011), suggest warmer conditions between $\sim 16000$ and 14550 cal yr BP (ORE-2). This interpretation is supported by the occurrence of warm-adapted littoral taxa such as Dicrotendipes nervosus-type, Pseudochironomus, and Tanytarsus pallidicornis-type 2 (Brooks et al., 2007; Heiri et al., 2011), which can typically be encountered in oligo- to mesotrophic lakes (Saether, 1979). The presence of the deep-water inhabitant Chironomus anthracinus-type, a taxon tolerant of low oxygen concentrations (Brooks et al., 2007), might reflect oxygen depletion of the lake water, possibly as a result of enhanced lake stratification associated with warmer climatic conditions (Ilyashuk et al., 2009). The increase in the profundal taxa Micropsectra insignilobus-type and Tanytarsus lugens-type (Brooks et al., 2007) towards the end of ORE2 coincides with decreasing abundances of Chironomus anthracinus-type and may reflect higher hypolimnetic oxygen concentrations.

Warm-adapted littoral taxa such as Dicrotendipes nervosus-type, Pseudochironomus, Tanytarsus pallidicornis-type, and Tanytarsus lactescens-type (Brooks et al., 2007) increase during ORE-3 ( 14 550-13000 cal yr BP), possibly as a result of warmer summers. Chironomus anthracinus-type displays maximum abundances, probably due to warmer temperatures, which favored lake stratification and therefore enhanced hypolimnetic oxygen consumption. Low oxygen concentrations possibly also led to the decline of Micropsectra insignilobus-type and limited the expansion of Tanytarsus lugens-type, which under temperate climatic conditions are both usually abundant in the profundal of well-oxygenated lakes (Hofmann, 1988; Clerk et al., 2000; Brooks et al., 2007; Brodersen and Quinlan, 2006). These taxa may have survived 
in the littoral of the lake, where oxygen was not a limiting factor (Brodersen and Quinlan, 2006).

Chironomus anthracinus-type and Tanytarsus lactescenstype decreased between $\sim 13000$ and 11600 cal yr BP (ORE-4), probably as a result of cooler temperatures. The dominance of littoral taxa such as Microtendipes pedellustype, Dicrotendipes nervosus-type, and Pseudochironomus, which can be encountered in shallow lakes or in the littoral of deeper lakes (Brodersen and Quinlan, 2006), suggests that lake levels at that time may have been low and that the lake was slightly mesotrophic (Saether, 1979). The re-expansion of the cold-adapted taxon Micropsectra insignilobus-type, which usually occurs in the profundal, but may move into the littoral of cold lakes (Hofmann, 1984), suggests a cooler climate. In the section dated to $\sim 11600$ 11100 cal yr BP (ORE-5) the cold-adapted Tanytarsus lugens-type disappeared and warm-adapted, littoral chironomids such as Tanytarsus pallidicornis-type 2, Tanytarsus lactescens-type, and Glyptotendipes severini-type (Heiri and Lotter, 2010) increased, suggesting warmer climatic conditions. The dominance of littoral taxa, which are considered to be typical of mesotrophic lakes, such as for instance Glyptotendipes severini-type (Saether, 1979), indicates that the lake was shallow and possibly mesotrophic.

\subsection{Reconstructed temperatures}

The Origlio record provides the first chironomid-based temperature reconstruction south of the Alps, which covers most of the transition from the Full Glacial to the Holocene, including the treeless vegetation period before $\sim 16000$ cal yr BP (Fig. 6). During the Last Glacial Maximum (LGM, $\sim 23000-19000 \mathrm{cal} \mathrm{yr} \mathrm{BP}$ ) small and isolated forest patches had survived locally in unglaciated areas of northern Italy, as is unambiguously shown by well-dated high-resolution macrofossil and pollen records (e.g. Kaltenrieder et al., 2009). This suggests that in the warmest areas of northern Italy temperatures never fell significantly below $10^{\circ} \mathrm{C}$ during the summers of the LGM, since July air temperatures below $10^{\circ} \mathrm{C}$ usually limit tree and forest growth (Lang, 1994). According to the Origlio record (Tinner et al., 1999), deglaciation in the southern Alpine foreland had started significantly before $\sim 18000 \mathrm{cal} \mathrm{yr} \mathrm{BP}$, in line with increasing Northern Hemisphere summer insolation (Berger and Loutre, 1991) and increasing atmospheric $\mathrm{CO}_{2}$ concentrations (Smith et al., 1999; Lourantou et al., 2010) (Fig. 6). Our new chironomid record suggests that average July air temperatures prior to $\sim 16000 \mathrm{cal} \mathrm{yr} \mathrm{BP}$ were ca. $10^{\circ} \mathrm{C}$ at Origlio and thus more than $10^{\circ} \mathrm{C}$ cooler than today. July means around $10^{\circ} \mathrm{C}$ prior to $\sim 16000 \mathrm{cal} \mathrm{yr} \mathrm{BP}$ indeed explain the prevalence of treeless Juniperus shrub tundra (probably J. nana) at that time (Tinner et al., 1999).

Climate at Origlio became warmer in the period $\sim 16000$ 14550 cal yr BP with a fairly abrupt increase in temperature of about $2.5^{\circ} \mathrm{C}$ dated to $\sim 16000 \mathrm{cal} \mathrm{yr} \mathrm{BP}$. The age

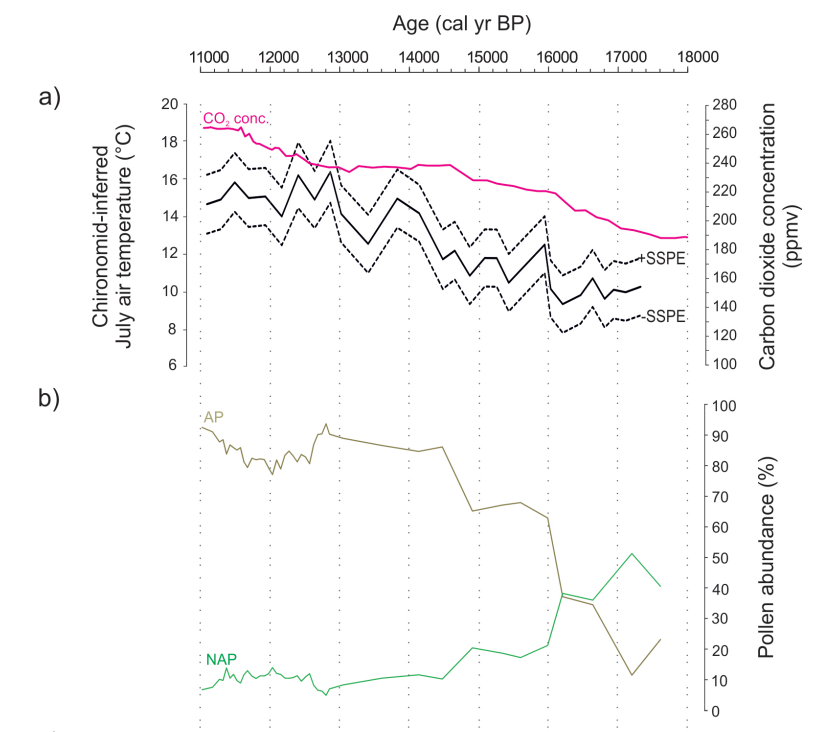

c)

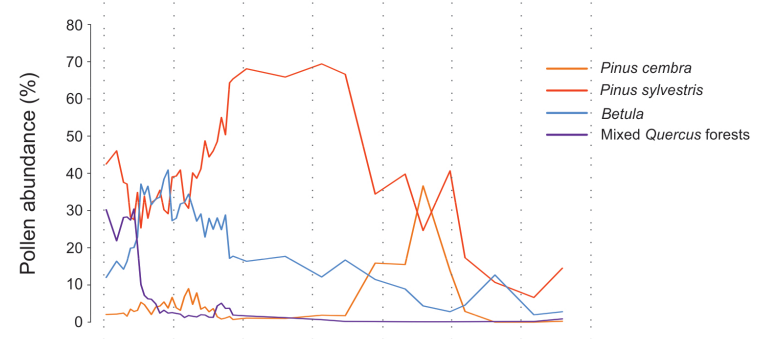

d)

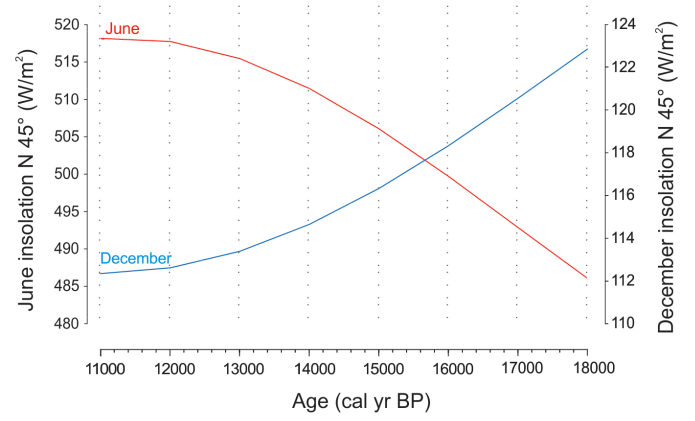

Fig. 6. (a) Chironomid-inferred July air temperature estimates including sample specific error of prediction (SSPE) compared with carbon dioxide concentration data from the European Project of Ice Coring in Antarctica (EPICA) (Lourantou et al., 2010); (b) pollen percentages of arboreal (AP) and non-arboreal pollen (NAP), and (c) of Pinus sylvestris, Pinus cembra, Betula, and mixed Quercus forests (Quercus, Ulmus, Tilia) of the Origlio sediment core (Tinner et al., 1999); (d) mean winter (December-February) and mean summer (June-August) insolation values at $45^{\circ} \mathrm{N}$ (Berger and Loutre, 1991).

of this early Late Glacial climatic warming south of the Alps is not well constrained in the Origlio record. However biostratigraphical comparison (mainly pollen) with other lowland sites in southern Switzerland and northern Italy shows that afforestation in the region started around $16000 \mathrm{cal}$ yr BP (Vescovi et al., 2007), providing independent evidence for the robustness of the Origlio age-depth 
model. For instance, at the nearby mire Balladrum (ca. $19 \mathrm{~km}$ distant to the northwest, $390 \mathrm{~m}$ a.s.l.) (Fig. 1) the pollen and macrofossil-inferred expansion of Pinus cembra forests is dated to $\sim 16500-16000$ cal yr BP (Pinus cembra macrofossils, $13100 \pm 100 \mathrm{yr}^{14} \mathrm{CBP}$, Hofstetter et al., 2006), showing that afforestation probably occurred some centuries prior to $\sim 16000 \mathrm{cal}$ yr BP. Other lowland pollen, stomata, and/or macrofossil records from Italy (Fig. 1) suggest afforestation 1.5-2 millennia before the onset of the Bølling interstadial. These records include Lago di Annone (Wick, 1996); Lago Piccolo di Avigliana (Finsinger et al., 2006); Lago di Ragogna (Wick, 2004); Fornaci di Revine (Friedrich et al., 1999); Lago di Ganna (Schneider and Tobolski, 1985). However, sites above ca. $1000 \mathrm{~m}$ a.s.l. remained unforested until the onset of the Bølling/Allerød interstadial.

Average chironomid-inferred July air temperatures $\sim 16000-14550 \mathrm{cal}$ yr BP reached $11.6^{\circ} \mathrm{C}$ at Origlio, which is sufficient to allow forest growth (Lang, 1994) and is thus in good agreement with the pollen, macrofossil, and stomata records at Origlio and elsewhere in the lowlands of the study region. If adjusted to Origlio altitudes using standard lapse rates of $6^{\circ} \mathrm{C} \mathrm{km}^{-1}$, chironomid-based temperature reconstructions for this period from mountain sites in the southern Alps (Heiri et al., 2007b; Samartin et al., 2012) range between 14.6 and $16.2^{\circ} \mathrm{C}$, which is about $3-4.5^{\circ} \mathrm{C}$ warmer than the Origlio reconstruction. However, a disagreement of ca. $3{ }^{\circ} \mathrm{C}$ is within the method-inherent reconstruction errors $\left( \pm 1.5-1.6^{\circ} \mathrm{C}\right.$ SSPE). Furthermore, local climatic effects such as adiabatic winds, temperature lapse rates, and the mass elevation effect of the Central Alpine mountain range (Landolt, 1992) may have affected local temperatures and been more variable in the Late Glacial period than today.

The early Late Glacial warming at $\sim 16000 \mathrm{cal}$ yr BP as inferred by chironomids is neither evidenced in the oxygenisotope records from Greenland ice cores (Björck et al., 1998; Svensson et al., 2008) nor in stable oxygen isotope studies of bulk sediments or ostracods in the Northern Alps (e.g. Lotter et al., 1992; von Grafenstein et al., 1999). Variations in these oxygen-isotope records are in good agreement with temperature changes reconstructed by other palaeoclimatic proxies from Europe north of the Alps such as chironomid records (e.g. Heiri and Millet, 2005; Heiri et al., 2007a; Larocque-Tobler, 2010; Lotter et al., 2012). Pollen sequences unambiguously document that north of the Alps afforestation did not start before the onset of the Bølling interstadial at $14700 \mathrm{cal}$ yr BP (e.g. Lotter, 1999; Litt et al., 2001, 2003). However, a chronologically poorly constrained, though characteristic expansion of Betula nana, evidenced both by pollen and macrofossils, occurred at many sites north of the Alps prior to the Bølling-Allerød interstadial. This dwarf birch phase has been attributed either to pedogenesis or to an increase in summer temperatures (Ammann and Tobolski, 1983; Gaillard, 1985), but has also been interpreted as the result of increasing atmospheric $\mathrm{CO}_{2}$ concentrations that started rising between $\sim 17000$ and $\sim 16500$ cal yr BP
(Lourantou et al., 2010). On the basis of the available dates (some on terrestrial macrofossils) the expansion of the dwarf birch tundra has been dated to $\sim 17500-15000$ cal yr BP (Welten, 1982; Ammann and Lotter, 1989). A substantial warming (to values of $15^{\circ} \mathrm{C}$ for mean July temperature and $0^{\circ} \mathrm{C}$ for mean January temperature) has been inferred based on few coleopteran taxa at the beginning of the dwarf birch phase (Gaillard and Lemdahl, 1994). Other insect records from the Swiss Plateau suggest lower mean July temperatures of $10-12{ }^{\circ} \mathrm{C}$ for the period before the onset of the Bølling-Allerød interstadial (Elias and Wilkinson, 1983). At Schleinsee (southern Germany) Wagner-Cremer and Lotter (2011) inferred an increase in growing degree-days (cumulative temperature $>5^{\circ} \mathrm{C}$ ) and hence an extension of the growing season before the onset of the Bølling-Allerød interstadial. This evidence is based on epidermal cell morphology of Betula nana leaves and again chronologically not well constrained. According to the only available radiocarbon date this event may have an age of 15 400-14 $700 \mathrm{cal}$ BP and is hence significantly younger than $16500-16000 \mathrm{cal} \mathrm{BP}$.

Further south, in France and Turkey, carbon isotopes of stalagmite records suggest soil and vegetation development in response to climate warming as early as $\sim 16000-15900$ cal yr BP, whereas stalagmites from Israel show similar environmental developments already at $\sim 19000$ cal yr BP (Bar-Matthews et al., 1999, 2003; Genty et al., 2006; Fleitmann et al., 2009) (Fig. 7). Climatic warming before the Bølling/Allerød interstadial is also recorded in Mediterranean and North Atlantic marine sequences. Alkenone-derived sea surface temperature reconstructions as well as $\delta^{18} \mathrm{O}$ measurements on foraminifera from the western Mediterranean Sea suggest a gradual Late Glacial warming that started between $\sim 18000$ and $\sim 17000 \mathrm{cal} \mathrm{yr} \mathrm{BP}$ (Cacho et al., 1999, 2001) (Fig. 7), whereas sea surface temperatures increased in the subtropical North Atlantic at about $17500 \mathrm{cal} \mathrm{yr} \mathrm{BP} \mathrm{(Chapman} \mathrm{et} \mathrm{al.,} \mathrm{1996)} \mathrm{and}$ at around $17000 \mathrm{calyr} \mathrm{BP}$ in the Iberian margin of the North Atlantic (Naughton et al., 2009). This early warming has been associated with a recovery of the meridional overturning circulation in the Atlantic Ocean between $\sim 18000$ and $\sim 17000 \mathrm{cal} \mathrm{yr} \mathrm{BP}$ (McManus et al., 2004). The slight oceanic warming along the Iberian margin was probably accompanied by an atmospheric warming, which led to a pollen-inferred expansion of Pinus forests on the Iberian Peninsula at ca. 17000 cal yr BP as dated based on marine sediments (Naughton et al., 2009). Warming before the onset of the Bølling interstadial is also documented in other regions and continents of the Northern Hemisphere. Decreasing $\delta^{18} \mathrm{O}$ values in stalagmites from Hulu and Tangshan caves (China) between $\sim 15800$ and $\sim 15000$ cal yr BP imply a more intense East Asian monsoon, probably because of warmer temperatures (Wang et al., 2001; Zhao et al., 2003). In the North Pacific warming is recorded in marine sequences at about $16750 \mathrm{cal}$ yr BP (Hill et al., 2006). 


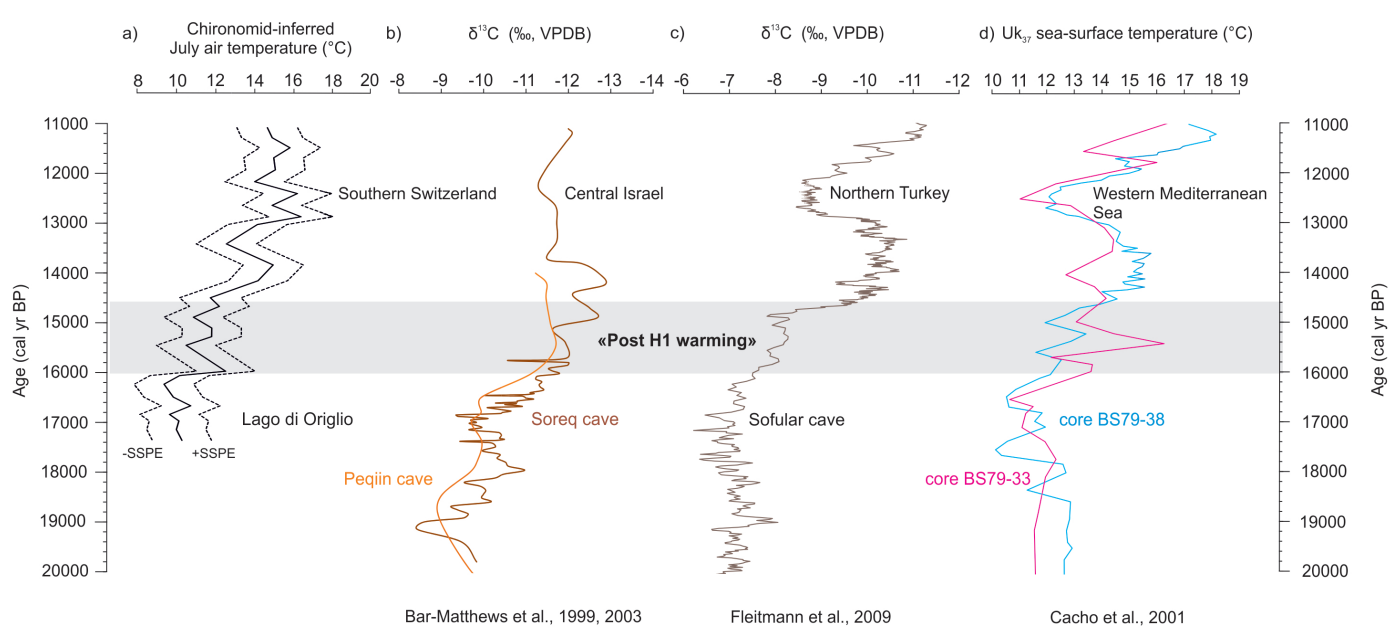

Fig. 7. (a) Chironomid-inferred July air temperature estimates (including sample specific error of prediction: SSPE), (b) carbon isotope data from Soreq and Peqiin caves in central Israel (Bar-Matthews et al., 1999, 2003) and (c) from Sofular cave in northern Turkey (Fleitmann et al., 2009), and (d) alkenone-derived sea surface temperature data from two sediment cores (BS79-33 and BS79-38) from the western Mediterranean Sea (Cacho et al., 2001).

At Origlio, the onset of the Bølling/Allerød interstadial was characterized by an abrupt warming of ca. $2.5-3.2^{\circ} \mathrm{C}$ at about $14550 \mathrm{cal}$ yr BP, with July air temperatures reaching on average ca. $14^{\circ} \mathrm{C}$. Simultaneously, vegetation dynamics at Origlio show that an abrupt change in forest composition and density occurred at $\sim 14550$ cal yr BP, when timberline Pinus cembra woodland was replaced by dense Pinus sylvestris and Betula forests (Fig. 6; Tinner et al., 1999). At the same time, tundra or alpine vegetation between 1000 and $1600 \mathrm{~m}$ a.s.l. was abruptly displaced by forests in southern Switzerland and northern Italy and this upslope migration of forests was coeval with the first woodland expansion north of the Alps (Vescovi et al., 2007).

A temperature increase in the range of $2-4{ }^{\circ} \mathrm{C}$ at the onset of the Bølling-Allerød interstadial was also recorded in chironomid records from northern Italy (Heiri et al., 2007b; Larocque and Finsinger, 2008), the Jura Mountains (Heiri and Millet, 2005), and the Northern Alps (Larocque-Tobler, 2010; Lotter et al., 2012). Wagner-Cremer and Lotter (2011) reconstructed for Schleinsee, southern Germany, an increase from 600 to 700 growing degree-days. This shift was simultaneous with the shift in oxygen isotopes in bulk carbonate towards higher values at the onset of Bølling-Allerød interstadial. The Bølling/Allerød interstadial is considered to represent the same event as GI- 1 in the NGRIP $\delta^{18} \mathrm{O}$ record, the onset of which has an estimated age of ca. 14650 cal yr BP $(0=1950$ AD) (Svensson et al., 2008). The age for the beginning of the Bølling/Allerød interstadial of $14550 \mathrm{cal} \mathrm{yr} \mathrm{BP}$ in the Origlio record is thus in good agreement with other northern-hemispherical records considering the chronological uncertainty of ca. $\pm 235 \mathrm{yr}$ for this period.

The general course of temperature at Origlio during the Bølling/Allerød interstadial agrees with other chironomid-based temperature reconstructions from Italy and the Alps (Heiri and Millet, 2005; Heiri et al., 2007b; Larocque and Finsinger, 2008; Ilyashuk et al., 2009; Larocque-Tobler, 2010; Samartin et al., 2012). However, in contrast to the Greenland NGRIP $\delta^{18} \mathrm{O}$ record (Svensson et al., 2008), which shows a gradual declining temperature trend since the onset of the Bølling-Allerød interstadial, the Origlio record, as well as other European chironomidinferred temperature records (e.g. Heiri and Millet, 2005), shows a gradually increasing trend in summer temperatures, whereas the Ammersee $\delta^{18} \mathrm{O}$ record shows rather stable temperatures (von Grafenstein et al., 1999). New multiproxy evidence from Gerzensee (Lotter et al., 2012) suggests that changes in insolation-forced seasonality may have contributed to this contrasting evidence. Pollen-reconstructed temperatures and oxygen-isotopes at Gerzensee show declining temperatures throughout the Bølling/Allerød interstadial, which are comparable to the Greenland oxygen-isotope records, while chironomid-based reconstructions again suggest increasing summer temperature trends (Lotter et al., 2012). It is likely that chironomids are more indicative for summer temperature changes than (perennial) plants and oxygen isotopes. The chironomid record at Gerzensee may therefore reflect a summer-insolation driven warming trend, while pollen and oxygen isotopes may also reflect declining temperatures in response to decreasing winter insolation. Vegetation evidence supports the chironomidinferred palaeotemperature estimates at Origlio with summer warmth-loving mixed oak forests expanding in the region towards the end of the Allerød (Vescovi et al., 2007; Fig. 6).

Reconstructed Bølling/Allerød temperatures are significantly cooler at Origlio than at other sites in northern Italy (Heiri et al., 2007b; Larocque and Finsinger, 2008), 
if corrected for altitude using standard lapse rates $\left(14^{\circ} \mathrm{C}\right.$ vs. ca. $\left.18.5-19.6^{\circ} \mathrm{C}\right)$. Chironomid-inferred temperatures at Origlio during the Bølling/Allerød are relatively close to the warmer limit of the temperature gradient in the modern training set used to develop the applied transfer function, which may have influenced the results. However the persistence of boreal forests (Pinus sylvestris, tree Betula, few Pinus cembra) in the lowlands despite the local presence of thermophilous taxa (e.g. Quercus, Tilia, Ulmus) since at least $\sim 13400 \mathrm{cal} \mathrm{yr} \mathrm{BP}$ (e.g. Finsinger et al., 2006), advocates against summer temperatures significantly higher than $15-16^{\circ} \mathrm{C}$. One possible reason for the differences of the available temperature reconstructions might be the different training sets used for temperature estimates, with the Swiss-Norwegian training set (July air temperature range 3.5-18.4 ${ }^{\circ} \mathrm{C}$; Heiri et al., 2011) permitting a good coverage of both European high- and mid-latitudes covering tundra, boreal, and temperate environments. Again, local climatic effects affecting the different sites to a varying extent may also play a role explaining these differences.

The Origlio pollen record indicates that forests declined only marginally during the Younger Dryas $(\sim 12750$ $11600 \mathrm{cal} y \mathrm{BP}$, Fig. 6), when steppic vegetation reexpanded together with Pinus cembra, Larix, and Betula. If compared with other chironomid-based temperature reconstructions from the Alps and Italy, average Younger Dryas temperatures at Origlio were comparable or slightly lower, if corrected for altitude $\left(15^{\circ} \mathrm{C}\right.$ vs. of $\left.15.7-18^{\circ} \mathrm{C}\right)$, but still within the errors of the records $\left( \pm 1.5-1.75^{\circ} \mathrm{C}\right.$ SSPE). In the Origlio record, chironomid-inferred July air temperatures decrease only slightly during the Younger Dryas period. However, similar results have been described from other European sites sheltered from the direct influence of the North Atlantic by Central European mountain ranges (e.g. in the southern Carpathians; Toth et al., 2012). Finally, for the earliest Holocene the chironomid record infers similar July air temperatures as for the preceding Allerød and Younger Dryas periods.

\section{Conclusions}

This study provides the first quantitative, non-pollen based evidence from Po-River catchment for a deglacial warming that took place $\sim 1500 \mathrm{yr}$ prior to the onset of the Bølling/Allerød interstadial. In agreement with these results, the forest succession in the formerly glaciated areas of northern Italy and southern Switzerland occurred ca. 1.5 millennia prior to the onset of similar afforestation processes north of the Alps and can be explained by a climate warming after Heinrich event 1 at $\sim 16700-16000$ cal yr BP.

The early deglacial warming observed in the Origlio record and elsewhere in southern Europe (e.g. southern France, Turkey) as well as in several marine palaeoclimate records probably reflects the integration of both regional, northern hemispheric, and global influences. Minor oscillations in the northward Atlantic heat transport were likely sufficient to restrict the entrance of cold waters trough the Strait of Gibraltar, causing the early post Heinrich event 1 warming in the Mediterranean realm (Cacho et al., 2001) (Fig. 7).

Warming between $\sim 16700-16000 \mathrm{calyrBP}$ in the Mediterranean realm, coupled with rising atmospheric $\mathrm{CO}_{2}$ concentrations was sufficient to allow forest spread where moisture availability was not limiting tree growth. The crucial role of moisture for forest growth in the Mediterranean is evidenced by the striking postglacial afforestation gradient along the Italian Peninsula, which is inverse to temperature (Tinner et al., 2009). Forests expanded at $\sim 16500-16000$ in northern Italy (Vescovi et al., 2007) and at $\sim 14500-13000$ cal yr BP in central (Magri, 1999; Magri and Sadori, 1999; Drescher-Schneider et al., 2007; Colombaroli et al., 2008) and southern Italy (Allen et al., 2002), whereas afforestation was delayed until ca. 10000 cal yr BP in the upland areas (Sadori and Narcisi, 2001) and until $\sim 7000$ cal yr BP in the drier (and warmest) coastal lowlands of Sicily (Tinner et al., 2009).

At present evidence for a similar early summer temperature warming north of the Alps as the one detected in northern Italy is sparse. Since the region north of the Alps was deforested and potentially affected by a tree immigration lag, palaeobotanical proxy records cannot resolve this question. Other comparable, well-dated, and quantitative summer temperature records are presently lacking. However, it is likely that a marked summer temperature gradient existed between Southern Europe and the rest of the continent, where unambiguous evidence of a warming in the period $\sim 16000-16700 \mathrm{cal} \mathrm{BP}$ is lacking. The huge ice sheets that were still covering wide parts of Northern Europe at that time will have affected atmospheric circulation in Northern and Central Europe. In addition, the final recovery of the meridional overturning circulation in the North Atlantic did not occur before the onset of the Bølling/Allerød interstadial (McManus et al., 2004). Therefore, ocean circulation recovery after Heinrich event 1 may have been insufficient to trigger substantial climatic warming in Central and Northern Europe prior to $\sim 14600 \mathrm{cal} \mathrm{yr} \mathrm{BP}$. This implies that between $\sim 16700$ (end of Heinrich event 1) and $\sim 14700$ (onset of Bølling/Allerød interstadial), meltwater events and associated variations in ocean circulation contributed to a north-south temperature gradient in Europe, which may have been significantly steeper than after the recovery of the Atlantic meridional overturning circulation when northern hemispherical ice coverage quickly decreased (McManus et al., 2004).

Acknowledgements. We acknowledge support by the Swiss National Science Foundation (project PP00P2-114886) and are grateful to Stephen Brooks for providing access to calibration data.

Edited by: M. Magny 


\section{References}

Allen, J. R. M., Watts, W. A., McGee, E., and Huntley, B.: Holocene environmental variability - the record from Lago Grande di Monticchio, Italy: The Value of Annually Laminated Sediments in Palaeoenvironment Reconstructions: Dedicated to Bjorn E. Berglund, Quatern. Int., 88, 69-80, 2002.

Ammann, B. and Lotter, A. F.: Late-Glacial radiocarbon- and palynostratigraphy on the Swiss Plateau, Boreas, 18, 109-126, 1989.

Ammann, B. and Tobolski, K.: Vegetational development during the Late-würm at Lobsigensee (Swiss Plateau): Studies in the Late Quaternary of Lobsigensee 1, Revue de Paléobiologie, Genève, 2, 163-180, 1983.

Bar-Matthews, M., Ayalon, A., Kaufman, A., and Wasserburg, G. J.: The Eastern Mediterranean paleoclimate as a reflection of regional events: Soreq cave, Israel, Earth Planet. Sc. Lett., 166, 85-95, 1999.

Bar-Matthews, M., Ayalon, A., Gilmour, M., Matthews, A., and Hawkesworth, C. J.: Sea-land oxygen isotopic relationships from planktonic foraminifera and speleothems in the Eastern Mediterranean region and their implication for paleorainfall during interglacial intervals: A Special Issue Dedicated to Robert Clayton, Geochim. Cosmochim. Acta, 67, 3181-3199, doi:10.1016/S0016-7037(02)01031-1, 2003.

Bennett, K. D.: Determination of the Number of Zones in a Biostratigraphical Sequence, New Phytol., 132, 155-170, 1996.

Berger, A. and Loutre, M. F.: Insolation values for the climate of the last 10000000 years, Quaternary Sci. Rev., 10, 297-317, 1991.

Birks, H. J. B.: Quantitative palaeoenvironmental reconstructions, in: Statistical Modelling of Quaternary Science Data, edited by: Maddy, D. and Brew, J. S., Quaternary Research Association technical guide, no. 5, Quaternary Research Association, Cambridge, 161-254, 1995.

Birks, H. J. B. and Gordon, A. D. (Eds.): Numerical Methods in Quaternary Pollen Analysis, Academic Press, London, 1985.

Birks, H. J. B., Line, J. M., Juggins, S., Stevenson, A. C., and ter Braak, C. J. F.: Diatoms and pH Reconstruction, Philos. T. Roy. Soc. Lond. B, 327, 263-278, 1990.

Birks, H. J. B., Heiri, O., Seppä, H., and Bjune, A. E.: Strenghts and Weaknesses of Quantitative Climate Reconstructions Based on Late-Quaternary Biological Proxies, Open Ecol. J., 3, 68-110, 2010.

Björck, S., Walker, M. J. C., Cwynar, L. C., Johnsen, S., Knudsen, K. L., Lowe, J. J., and Wohlfarth, B.: An event stratigraphy for the Last Termination in the North Atlantic region based on the Greenland ice-core record: a proposal by the INTIMATE group, J. Quaternary Sci., 13, 283-292, 1998.

Brodersen, K. P. and Quinlan, R.: Midges as palaeoindicators of lake productivity, eutrophication and hypolimnetic oxygen: Quaternary beetle research: the state of the art, Quaternary Sci. Rev., 25, 1995-2012, 2006.

Brooks, S. J.: The responnse of Chironomidae (Insecta: Diptera) assemblages to Late-glacial climatic change in Kråkenes lake, Western Norway, Quaternary proceedings, vol. 5, 49-58, 1997.

Brooks, S. J.: Fossil midges (Diptera: Chironomidae) as palaeoclimatic indicators for the Eurasian region, Quaternary Sci. Rev., 25, 1894-1910, 2006.

Brooks, S. J. and Birks, H. J. B.: Chironomid-inferred Late-glacial air temperatures at Whitrig Bog, Southeast Scotland, J. Quaternary Sci., 15, 759-764, 2000.
Brooks, S. J. and Birks, H. J. B.: Chironomid-inferred air temperatures from Lateglacial and Holocene sites in north-west Europe: progress and problems, Quaternary Sci. Rev., 20, 1723-1741, 2001.

Brooks, S. J., Langdon, P. G., and Heiri, O. (Eds.): The identification and use of palaearctic chironomidae larvae in palaeoecology, Technical Guide, 10, Quaternary Research Association, London, 275 pp., 2007.

Cacho, I., Grimalt, J. O., Pelejero, C., Canals, M., Sierro, F. J., Flores, J. A., and Shackleton, N.: Dansgaard-Oeschger and Heinrich Event Imprints in Alboran Sea Paleotemperatures, Paleoceanography, 14, 698-705, 1999.

Cacho, I., Grimalt, J. O., Canals, M., Sbaffi, L., Shackleton, N. J., Schönfeld, J., and Zahn, R.: Variability of the western Mediterranean Sea surface temperature during the last 25,000 years and its connection with the Northern Hemisphere climatic changes, Paleoceanography, 16, 40-52, 2001.

Chapman, M. R., Shackleton, N. J., Zhao, M., and Eglinton, G.: Faunal and Alkenone Reconstructions of Subtropical North Atlantic Surface Hydrography and Paleotemperature Over The last 28 kyr, Paleoceanography, 11, 343-357, 1996.

Clerk, S., Hall, R., Quinlan, R., and Smol, J. P.: Quantitative inferences of past hypolimnetic anoxia and nutrient levels from a Canadan Precambrian Shield lake, J. Paleolimnol., 23, 319-336, 2000.

Colombaroli, D., Vanniere, B., Emmanuel, C., Magny, M., and Tinner, W.: Fire-vegetation interactions during the MesolithicNeolithic transition at Lago dell'Accesa, Tuscany, Italy, Holocene, 18, 679-692, 2008.

Drescher-Schneider, R., De Beaulieu, J.-L., Magny, M., WalterSimonnet, A.-V., Bossuet, G., Millet, L., Brugiapalia, E., and Drescher, A.: Vegetation history, climate and human impact over the last 15,000 years at Lago dell'Accesa (Tuscany, Central Italy), Veg. Hist. Archaeobot., 16, 279-299, 2007.

Elias, S. A. and Wilkinson, B.: Lateglacial insect fossil assemblages from Lobsigensee (Swiss Plateau), Studies in the Late Quaternary of Lobsigensee 3, Revue de Paléobiologie, 2, 189-204, 1983.

Finsinger, W., Tinner, W., van der Knaap, W. O., and Ammann, B.: The expansion of hazel (Corylus avellana L.) in the southern Alps: a key for understanding its early Holocene history in Europe?, Quaternary Sci. Rev., 25, 612-631, 2006.

Fleitmann, D., Cheng, H., Badertscher, S., Edwards, R. L., Mudelsee, M., Göktürk, O. M., Fankhauser, A., Pickering, R., Raible, C. C., Matter, A., Kramers, J., and Tüysüz, O.: Timing and climatic impact of Greenland interstadials recorded in stalagmites from northern Turkey, Geophys. Res. Lett, 36, L19707, doi:10.1029/2009GL040050, 2009.

Friedrich, M., Kromer, B., Spurk, M., Hofmann, J., and Kaiser, K.: Paleo-environmental and radiocarbon calibration as derived from Lateglacial/Early Holocene tree-ring chronologies, Quatern. Int., 61, 27-39, 1999.

Gaillard, M. J.: Postglacial palaeoclimatic changes in Scandinavia and Central Europe. A tentative correlation based on studies of lake level fluctuations, Ecologia Mediterranea, Marseille, 11, 159-175, 1985.

Gaillard, M. J. and Lemdahl, G.: Lateglacial insect assemblages from Grand Marais, south-western Switzerland - climatic implications and comparison with pollen and plant macrofossil 
data, in: Festschrift Gerhard Lang: Beiträge zur Systematik und Evolution, Floristik und Geobotanik, Vegetationsgeschichte und Paläoökologie, edited by: Lotter, A., Dissertationes botanicae, 234, Cramer, Berlin, Stuttgart, 287-308, 1994.

Genty, D., Blamart, D., Ghaleb, B., Plagnes, V., Causse, C., Bakalowicz, M., Zouari, K., Chkir, N., Hellstrom, J., Wainer, $\mathrm{K}$., and Bourges, F.: Timing and dynamics of the last deglaciation from European and North African $\delta^{13} \mathrm{C}$ stalagmite profiles - comparison with Chinese and South Hemisphere stalagmites, Quaternary Sci. Rev., 25, 2118-2142, 2006.

Heaton, T. J., Blackwell, P. G., and Buck, C. E.: A Bayesion approach to the estimation of radiocarbon calibration curves: the INTCAL09 methodology, Radiocarbon, 51, 1151-1164, 2009.

Heiri, O. and Lotter, A. F.: Effect of low count sums on quantitative environmental reconstructions: an example using subfossil chironomids, J. Paleolimnol., 26, 343-350, 2001.

Heiri, O. and Lotter, A. F.: Holocene and Lateglacial summer temperature reconstruction in the Swiss Alps based on fossil assemblages of aquatic organisms: a review, Boreas, 34, 506-516, 2005.

Heiri, O. and Lotter, A. F.: How does taxonomic resolution affect chironomid-based temperature reconstruction?, J. Paleolimnol., 44, 589-601, 2010.

Heiri, O. and Millet, L.: Reconstruction of Late Glacial summer temperatures from chironomid assemblages in Lac Lautrey (Jura, France), J. Quaternary Sci., 20, 33-44, 2005.

Heiri, O., Lotter, A. F., Hausmann, S., and Kienast, F.: A chironomid-based Holocene summer air temperature reconstruction from the Swiss Alps, Holocene, 13, 477-484, 2003.

Heiri, O., Cremer, H., Engels, S., Hoek, W. Z., Peeters, W., and Lotter, A. F.: Lateglacial summer temperatures in the Northwest European lowlands: a chironomid record from Hijkermeer, the Netherlands, Quaternary Sci. Rev., 26, 2420-2437, 2007a.

Heiri, O., Filippi, M. L., and Lotter, A. F.: Lateglacial summer temperatures in the Trentino area (Northern Italy) as reconstructed by fossil chironomid assemblages in Lago di Lavarone (1100 m a.s.1.), Studi Trentini di Scienze Naturali, Acta Geologica, 299-308, 2007b.

Heiri, O., Brooks, S. J., Birks, H. J. B., and Lotter, A. F.: A 274-lake calibration data-set and inference model for chironomid-based summer air temperature reconstruction in Europe, Quaternary Sci. Rev., 30, 3445-3456, 2011.

Hill, M. O.: Diversity and evenness: A unifying notation and its consequences, Ecology, 54, 427-432, 1973.

Hill, T. M., Kennett, J. P., Pak, D. K., Behl, R. J., Robert, C., and Beaufort, L.: Pre-Bølling warming in Santa Barbara Basin, California: surface and intermediate water records of early deglacial warmth, Quaternary Sci. Rev., 25, 2835-2845, 2006.

Hofmann, W.: Stratigraphie subfossiler Cladocera (Crustacea) and Chironomidae (Diptera) in zwei Sedimentprofilen des Meerfelder Maares, Courier Forschungs Institut Senckenberg, 65, 6780, 1984.

Hofmann, W.: The significance of chironomid analysis (Insecta: Diptera) for paleolimnological research, Palaeogeogr. Palaeocl., 62, 501-509, 1988.

Hofstetter, S., Tinner, W., Valsecchi, V., Carraro, G., and Conedera, M.: Lateglacial and Holocene vegetation history in the Insubrian Southern Alps - New indications from a small-scale site, Veg. Hist. Archaeobot., 15, 87-98, 2006.
Ilyashuk, B. P., Gobet, E., Heiri, O., Lotter, A. F., van Leeuwen, J. F. N., van der Knaap, W. O., Ilyashuk, E. A., Oberli, F., and Ammann, B.: Lateglacial environmental and climatic changes at the Maloja Pass, Central Swiss Alps, as recorded by chironomids and pollen, Quaternary Sci. Rev., 28, 1340-1353, 2009.

Kaltenrieder, P., Belis, C. A., Hofstetter, S., Ammann, B., Ravazzi, C., and Tinner, W.: Environmental and climatic conditions at a potential Glacial refugial site of tree species near the Southern Alpine glaciers. New insights from multiproxy sedimentary studies at Lago della Costa (Euganean Hills, Northeastern Italy), Quaternary Sci. Rev., 28, 2647-2662, doi:10.1016/j.quascirev.2009.05.025, 2009.

Juggins, S.: C2 User Guide: Software for Ecological and Palaeoecological Data Analysis and Visualisation, University of Newcastle, Newcastle, 2007.

Landolt, E.: Unsere Alpenflora, 6. vollst. neu bearb., Fischer, Stuttgart, 120 pp., 1992.

Lang, G.: Quartäre Vegetationsgeschichte Europas: Methoden und Ergebnisse, G. Fischer, Jena, 462 pp., 1994.

Larocque, I. and Finsinger, W.: Late-glacial chironomid-based temperature reconstructions for Lago Piccolo di Avigliana in the southwestern Alps (Italy), Palaeogeogr. Palaeocl., 257, 207-223, 2008.

Larocque-Tobler, I.: Reconstructing temperature at Egelsee, Switzerland, using North American and Swedish chironomid transfer functions: potential and pitfalls, J. Paleolimnol., 44, 243251, 2010.

Litt, T., Brauer, A., Goslar, T., Merkt, J., Bałaga, K., Müller, H., Ralska-Jasiewiczowa, M., Stebich, M., and Negendank, J. F. W.: Correlation and synchronisation of Lateglacial continental sequences in northern central Europe based on annually laminated lacustrine sediments: INTIMATE, Quaternary Sci. Rev., 20, 1233-1249, 2001.

Litt, T., Schmincke, H.-U., and Kromer, B.: Environmental response to climatic and volcanic events in central Europe during the Weichselian Lateglacial: Environmental response to climate and human impact in central Europe during the last 15000 years - a German contribution to PAGES-PEPIII, Quaternary Sci. Rev., 22, 7-32, 2003.

Lotter, A. F.: Late-Glacial and Holocene vegetation history and dynamics as shown by pollen and plant macrofossil analysis in anually laminated sediments from Soppensee, central Switzerland, Veg. Hist. Archaeobot., 8, 165-184, 1999.

Lotter, A. F., Eicher, U., Siegenthaler, U., and Birks, H. J. B.: Lateglacial climatic oscillations as recorded in Swiss lake sediments, J. Quaternary Sci., 7, 187-204, 1992.

Lotter, A. F., Birks, H. J. B., Hofmann, W., and Marchetto, A.: Modern diatom, cladocera, chironomid, and chrysophyte cyst assemblages as quantitative indicators for the reconstruction of past environmental conditions in the Alps. I. Climate, J. Paleolimnol., 18, 395-420, 1997.

Lotter, A. F., Heiri, O., Brooks, S., van Leeuwen, J. F. N., Eicher, U., and Ammann, B.: Rapid summer temperature changes during Termination 1a: high-resolution multi-proxy climate reconstructions from Gerzensee (Switzerland), Quaternary Sci. Rev., 36, 103-113, 2012. 
Lourantou, A., Lavrič, J. V., Köhler, P., Barnola, J.-M., Paillard, D., Michel, E., Raynaud, D., and Chappellaz, J.: Constraint of the $\mathrm{CO}_{2}$ rise by new atmospheric carbon isotopic measurements during the last deglaciation, Global Biogeochem. Cy., 24, GB2015, doi:10.1029/2009GB003545, 2010.

Magri, D.: Late Quaternary vegetation history at Lagaccione near Lago di Bolsena (central Italy), Rev. Palaeobot. Palynol., 106, 171-208, 1999

Magri, D. and Sadori, L.: Late Pleistocene and Holocene pollen stratigraphy at Lago di Vico, central Italy, Veg. Hist. Archaeobot., 8, 247-260, 1999.

McManus, J. F., Francois, R., Gherardi, J.-M., Keigwin, L. D., and Brown-Leger, S.: Collapse and rapid resumption of Atlantic meridional circulation linked to deglacial climate changes, Nature, 428, 834-837, 2004.

Merk, J. and Streif, H.: Stechrohr-Bohrgeräte für limnische und marine Lockersedimente, Geologisches Jahrbuch, 88, 137-148, 1970.

Müller, B., Lotter, A. F., Sturm, M., and Ammann, B.: The in?uence of catchment and geographic location on the water and sediment composition of 68 small circumalpine lakes, Aquat. Sci., 60, 316-337, 1998.

Naughton, F., Sánchez Goñi, M. F., Kageyama, M., Bard, E., Duprat, J., Cortijo, E., Desprat, S., Malaizé, B., Joly, C., Rostek, F., and Turon, J.-L.: Wet to dry climatic trend in north western Iberia within Heinrich events, Earth Planet. Sc. Lett., 284, 329342, 2009.

Reimer, P. J., Baillie, M. G. L., and Bard, E. E. A.: IntCal04 Terrestrial radiocarbon age calibration 26-0 ka BP, Radiocarbon, 46, 1029-1058, 2004.

Rieradevall, M. and Brooks, S. J.: An identification guide to subfossil Tanypodinae larvae (Insecta: Diptera: Chrironomidae) based on cephalic setation, J. Paleolimnol., 25, 81-99, 2001.

Sadori, L. and Narcisi, B.: The Postglacial record of environmental history from Lago di Pergusa, Sicily, Holocene, 11, 655-671, 2001.

Saether, O. A.: Chironomid communities as water quality indicators, Holarctic Ecol., 2, 65-74, 1979.

Samartin, S., Heiri, O., Vescovi, E., Brooks, S. J., and Tinner, W.: Lateglacial and early Holocene summer temperatures in the southern Swiss Alps reconstructed using fossil chironomids, J. Quaternary Sci., 27, 279-289, doi:10.1002/jqs.1542, 2012.

Schmid, P. E. (Ed.): A key to the larval Chironomidae and their instars from Austrian Danube region streams and rivers: with particular reference to a numerical taxonomic approach, Wasser und Abwasser Supplement, 3/93, Federal Institute for Water Quality, Wien, 512 pp., 1993.

Schneider, R. and Tobolski, K.: Lago di Ganna - Lateglacial and Holocene environments of a Lake in the Southern Alps, Dissert. Botanicae, 87, 229-271, 1985.

Smith, H. J., Fischer, H., Wahlen, M., Mastroianni, D., and Deck, B.: Dual modes of the carbon cycle since the Last Glacial Maximum, Nature, 400, 248-250, 1999.

Stanford, J. D., Rohling, E. J., Bacon, S., Roberts, A. P., Grousset, F. E., and Bolshaw, M.: A new concept for the paleoceanographic evolution of Heinrich event 1 in the North Atlantic, Quaternary Sci. Rev., 30, 1047-1066, 2011.
Svensson, A., Andersen, K. K., Bigler, M., Clausen, H. B., DahlJensen, D., Davies, S. M., Johnsen, S. J., Muscheler, R., Parrenin, F., Rasmussen, S. O., Röthlisberger, R., Seierstad, I., Steffensen, J. P., and Vinther, B. M.: A 60000 year Greenland stratigraphic ice core chronology, Clim. Past, 4, 47-57, doi:10.5194/cp-4-472008, 2008.

ter Braak, C. and Juggins, S.: Weighted averaging partial least squares regression (WA-PLS): an improved method for reconstructing environmental variables from species assemblages, Hydrobiologia, 269/270, 485-502, 1993.

ter Braak, C. and Šmilauer, P.: CANOCO Reference Manual and User's Guide to Canoco for Windows: Software for Canonical Community Ordination (version 4.5), Microcomputer Power, Ithaca, NY, 2002.

ter Braak, C., Juggins, S., Birks, H. J. B., and van der Voet, H.: Weighted averaging partial least squares regression (WAPLS): definition and comparison with other methods for speciesenvironmental calibration, in: Multivariate Environmental Statistics, edited by: Patil, G. and Rao, C., Elsevier Science Publishers, Amsterdam, 525-560, 1993.

Thornton, P. E., Running, S. W., and White, M. A.: Generating surfaces of daily meteorological variables over large regions of complex terrain: Aggregate Description of Land-Atmosphere Interactions, J. Hydrol., 190, 214-251, 1997.

Tinner, W.: Quartärbotanische Untersuchungen zur Waldbrandökologie des Sottoceneri (Südschweiz): Inaugural Dissertation der Philosophisch-naturwissenschaftlichen Fakultät der Universität Bern, Bern, 1998.

Tinner, W., Hubschmid, P., Wehrli, M., Ammann, B., and Conedera, M.: Long-Term Forest Fire Ecology and Dynamics in Southern Switzerland, J. Ecol., 87, 273-289, 1999.

Tinner, W., Conedera, M., Ammann, B., and Lotter, A. F.: Fire ecology north and south of the Alps since the last ice age, Holocene, 15, 1214-1226, 2005.

Tinner, W., van Leeuwen, J. F. N., Colombaroli, D., Vescovi, E., van der Knaap, W. O., Henne, P. D., Pasta, S., D'Angelo, S., and La Mantia, T.: Holocene environmental and climatic changes at Gorgo Basso, a coastal lake in southern Sicily, Italy, Quaternary Sci. Rev., 28, 1498-1510, doi:10.1016/j.quascirev.2009.02.001, 2009.

Toth, M., Magyari, E., Brooks, S. J., Braun, M., Buczkó, K., Bálint, M., and Heiri, O.: A chironomid-based reconstructions of lateglacial summer temperatures in the southern Carpathiens (Romania), Quatern. Res., 77, 122-131, 2012.

Veit, H. (Ed.): Die Alpen: Geoökologie und Landschaftsentwicklung, UTB Geowissenschaften, Ökologie, Biologie, 2327, Ulmer, Stuttgart (Hohenheim), 50, 2002.

Vescovi, E., Ravazzi, C., Arpenti, E., Finsinger, W., Pini, R., Valsecchi, V., Wick, L., Ammann, B., and Tinner, W.: Interactions between climate and vegetation during the Lateglacial period as recorded by lake and mire sediment archives in Northern Italy and Southern Switzerland, Quaternary Sci. Rev., 26, 1650-1669, 2007.

von Grafenstein, U., Erlenkeuser, H., Brauer, A., Jouzel, J., and Johnsen, S. J.: A Mid-European Decadal Isotope-Climate Record from 15,500 to 5000 cal Years B.P., Science, 284, 1654-1657, 1999. 
Wagner-Cremer, F. and Lotter, A. F.: Spring-season changes during the Late Pleniglacial and Bølling/Allerød interstadial, Quaternary Sci. Rev., 30, 1825-1828, 2011.

Wang, Y. J., Cheng, H., Edwards, R. L., An, Z. S., Wu, J. Y., Shen, C.-C., and Dorale, J. A.: A High-Resolution Absolute-Dated Late Pleistocene Monsoon Record from Hulu Cave, China, Science, 294, 2345-2348, 2001.

Welten, M.: Vegetationsgeschichtliche Untersuchungen in den westlichen Schweizer Alpen: Bern-Wallis, Denkschrift der Schweizerischen Naturforschenden Gesellschaft, 95, Birkhäuser, Basel, 1982.

Wick, L.: Lateglacial and Early-Holocene palaeoenvironments in Brianza, N Italy, Il Quaternario, 9, 653-660, 1996.
Wick, L.: Full to Lateglacial vegetation and climate change and evidence of glacial refugia in the South-Eastern Alps, in: XI International Palynological Congress (IPC), edited by: Ubera, J. L., University of Cordoba, Granada, 2004.

Wiederholm, T. (Ed.): Chironomidae of the Holoarctic region: Keys and diagnoses, Part 1. Larvae, Entomologica scandinavica, Lund, Supplement 19, 1-457, 1983.

Zhao, J.-X., Wang, Y.-J., Collerson, K. D., and Gagan, M. K.: Speleothem U-series dating of semi-synchronous climate oscillations during the last deglaciation, Earth Planet. Sc. Lett., 216, 155-161, 2003. 